\title{
DOES THE EUROPEAN DAMAGES DIRECTIVE MAKE CONSUMERS BETTER OFF?
}

\author{
Miriam C. Buiten ${ }^{*}$ Peter van Wijck ${ }^{\dagger}$, Jan Kees Winters ${ }^{\ddagger}$
}

Published in: Journal of Competition Law and Economics, 2018, 14(1), 91-114.

\begin{abstract}
In the enforcement of European competition law both public and private actors play a role. Public enforcement dominates. Leniency programs give cartelists incentives to reveal the cartel and disclose relevant information to the competition authority. The incentives originate from a reduction in sanctions. Directive 2014/104/EU aims at removing practical obstacles to compensation for victims of infringements of EU competition law. The literature suggests that facilitating private damages actions tends to limit the effectiveness of leniency programs. If victims are able to claim compensation, the incentive to apply for leniency may vanish.

In addition to the literature, this paper not only considers the effect of private damages on incentives to apply for leniency, but also explores the consequence for deterrence and consumer welfare. Specifically, this paper investigates the implications of an improvement in the claim position of victims for: 1. decisions to start or continue a cartel, 2. decisions to apply for leniency, and 3. consumer welfare. Cartelists' behavior is analyzed in a dynamic setting. The paper finds that a marginal improvement in the position of victims in most cases leads to an increase in consumer welfare but not in deterrence. In some cases it also leads to an increase in deterrence, and in exceptional cases makes consumers worse off since cartelists refrain from applying for leniency.
\end{abstract}

JEL: K13, K21, L41

\footnotetext{
* Junior Professor of Law and Economics at the Department of Law, University of Mannheim (buiten@uni-mannheim.de).

${ }^{\dagger}$ Associate Professor of Law and Economics at Leiden Law School (p.w.vanwijck@law.leidenuniv.nl).

${ }^{\ddagger}$ Principal at RBB Economics, The Hague (jankees.winters@rbbecon.com).

The authors wish to thank Damien Geradin, Tim Reuter and participants of the Leiden Law School research conference "Private law and market regulation - interaction, interference or inconsistency?”, the MaCCI Annual Conference 2017, and the Annual conference of the European Association of Law and Economics 2017, for useful comments and suggestions. The usual disclaimer applies.
} 


\section{INTRODUCTION}

Within the EU, traditionally public enforcement of competition law is the rule. Recently, however, the European Commission decided to stimulate private enforcement by introducing a Directive on antitrust damages actions ("Directive"). ${ }^{1}$ Infringements such as cartels or abuse of a dominant position in the market are detrimental to the economy, but they also cause concrete harm to victims. The Court of Justice of the European Union has established that any citizen or business has a right to full compensation for the harm caused to them by an antitrust infringement. ${ }^{2}$ However, in practice most victims, particularly SMEs and consumers, face several hurdles when attempting to obtain compensation. The Directive aims to remove the main obstacles to effective compensation, in order to facilitate antitrust damages actions. ${ }^{3}$ It moreover aims to fine-tune the interplay between public antitrust enforcement and private damages actions.

The literature, to be discussed in section III, suggests that facilitating private damages actions tends to limit the effectiveness of leniency programs. The line of reasoning is that if a member of a cartel does not apply for leniency and the cartel is detected by the competition authority, the members of the cartel will be punished by a fine, and will have to pay damages to injured parties. If, however, a firm does apply for leniency, this firm will be exempted from paying a fine, but still may have to pay damages. The air cargo case provides an example. As the whistleblower, Lufthansa escaped the fine, totaling €799 million combined for all eleven air cargo carriers in Europe. However, Lufthansa soon faced a $€ 3$ billion of damages claimed by just one claimant, Deutsche Bahn. ${ }^{4}$

This tension was explicitly formulated in the opinion of Advocate General Mazák in Pfleiderer: "Thus while a potential leniency applicant may benefit from immunity from or a reduction in fines, that benefit may be perceived as being outweighed by an increased risk of liability for damages where access to the leniency file is granted, particularly in cases in which cartel members are jointly and severally liable under national rules of civil procedure. A cartel member may therefore abstain from applying for leniency altogether or alternatively be less forthcoming with a competition authority during the leniency procedure." ${ }^{5}$

While the literature so far focuses on the potential undermining effect of damages claims on incentives to apply for leniency, damages claims also increase the expected costs of a cartel from an ex ante perspective. As a result, damages compensation may discourage firms from engaging in a cartel in the first place. This paper also considers this effect.

Moreover, we consider the possibility that victims may, in practice, only be able to claim partial damages compensation. Victims have the right to full compensation for the harm - a right the Directive aims to ensure by removing legal obstacles. Nevertheless, various practical hurdles may remain that may limit the possibilities for claimants to obtain full damages compensation. ${ }^{6}$

More specifically, we focus on the following question: What are the implications of an improvement in the victims' position for: 1 . decisions to start or continue a cartel, 2. decisions to apply for leniency, and 3. consumer welfare? In short: What are the implications of private enforcement for deterrence, leniency, and consumer welfare?

In order to address this question, we develop a dynamic model. The model elicits two possible effects of introducing partial compensation for victims. First, it may reduce incentives to apply for leniency, as has been found previously. Alternatively, liability for damages may lead firms to refrain from engaging in a cartel in the first place. The paper thus finds that partial compensation may also reinforce deterrence of antitrust enforcement.

Directive 2014/104/EU of the European Parliament and of the Council of 26 November 2014 on certain rules governing actions for damages under national law for infringements of the competition law provisions of the Member States and of the European Union, OJ L349/1, 5 December 2014 (http://eur-lex.europa.eu/legal-content/EN/TXT/PDF/?uri=CELEX:32014L0104\&from=EN). For the history, overview and development of the directive, see http://ec.europa.eu/competition/antitrust/actionsdamages/directive_en.html See Case C-453/99, Courage [2001] ECR I-6314 and Joined Cases C-295/04 and C-298/04, Manfredi [2006] ECR I-06619. See Article 1(1) of the Directive.

See http://europa.eu/rapid/press-release IP-10-1487 en.htm?locale=en and http://www.reuters.com/article/deutsche-bahn-airlinesidUSL6N0TK0GK20141130.

Opinion of Advocate General Mazák, delivered on 16 December 2010. Case C-360/09 Pfleiderer v Bundeskartellamt, par. 38.

This may be due, for instance, to the legal system which may not support victims to the extent needed, or to the imperfect information position of a victim, which will reduce his chances of winning a law suit. See further section II. 
To the best of our knowledge, this effect has not previously been illustrated in the literature. While some previous contributions consider the possibility of partial compensation, none have linked this to the decision of firms whether or not to enter into or continue a cartel. This paper thus aims to contribute to the existing literature on public and private antitrust enforcement by showing two opposing effects of the strength of the victims' claims on deterrence, and by illustrating the effect of private damages not only on the leniency program, but also on consumer welfare.

The paper is organized as follows. Section II discusses the legal position of the victim under the Directive, and the remaining obstacles to compensation. Section III gives a concise overview of the economic literature on the enforcement of competition law, leniency and cartel damages. Section IV presents a dynamic model to explain whether firms will form a cartel and, if so, whether or not they will apply for leniency in the presence of follow-on damages claims. Section V shows simulations of the implications of an improvement of the victims' legal position, in terms of higher compensation of their harm. Section VI presents conclusions.

\section{THE ANTITRUST DAMAGES DIRECTIVE}

Directive 2014/104/EU entered into force on 26 December 2014 and had to be implemented by the Member States by 27 December 2016. ${ }^{7}$ The Directive aims to remove the main obstacles to effective compensation for victims of competition law infringements, and to guarantee minimum protection for citizens and businesses everywhere in the EU. The Directive applies to all damages actions in the Member States, whether individual or collective. Further, the Directive aims to fine-tune the interplay between private damages actions and public enforcement of the EU antitrust rules by the Commission and national competition authorities. ${ }^{8}$

The Directive specifies that "any natural or legal person who has suffered harm caused by an infringement of competition law is able to claim and to obtain full compensation for that harm". ${ }^{9}$ Full compensation means that the victim will be placed in the position in which he would have been had the infringement not been committed. ${ }^{10}$ In order to facilitate claims, the Directive lays down rules with regard to the disclosure of evidence, the probative effect of decisions of national competition authorities, limitation periods, joint and several liability of defendants, the passing-on of overcharges, quantification of harm and settlements.

In this paper, we assume that victims may receive only partial compensation for their harm. We consider the impact of an improvement of the victims' position, meaning compensation for a larger part of his harm. This assumption requires some explanation, given that the Directive offers a right to full compensation, and given that we only consider follow-on claims, in which a competition authority has already established the existence of a cartel. The reason to consider partial compensation is that despite the new rights for claimants specified in the Directive, victims may still face a number of obstacles when filing a claim for damages compensation. The most important one, also in the view of the European Commission, is the difficulty to effectively secure the evidence needed to prove a claim for damages. ${ }^{11}$

At first glance, proving damages may not seem very problematic in the context of follow-on litigation, since in this case the victims have become aware of the existence of the cartel. Nevertheless, the knowledge that prices have been fixed at an artificially high level does not automatically translate into a full damages compensation for the victim. A first reason is that the victim may need access to documents of defendants in order to prove the damages suffered. While the Directive clarifies the possibilities for claimants to obtain access to documents, it shields leniency statements and settlement submissions from disclosure and offers temporal

\footnotetext{
See See Article 1(1) of the Directive and http://ec.europa.eu/competition/antitrust/actionsdamages/index.html. In September 2017, 6 member states still had not fully transposed the Directive into their legal systems.

See Recitals 6 and 9 of the Directive.

Article 3 (1) of the Directive.

Article 3(2) of the Directive.

11 Proposal for a Directive of The European Parliament and of The Council, on certain rules governing actions for damages under national law for infringements of the competition law provisions of the Member States and of the European Union COM (2013) 404 final, at 4.
} 
protection to various other types of information. ${ }^{12}$ As a result, even in a claim following a leniency application, the claimant may have difficulties proving the amount of his losses.

Secondly, although the Directive introduced a presumption that cartel infringements cause harm, ${ }^{13}$ the victim still needs to prove the actual existence and the amount of that harm, as well as the causal link between the cartel and the losses he suffered. Quantifying cartel damages is a complex task, and the defendants will generally provide courts with their own (more modest) calculations of the harm. The difficulty lies in determining the price that would have applied had the cartel not existed. This requires statistical tools and includes numerous factors, so that one exact number usually cannot be given. It is up to the court to evaluate which scenario it considers most realistic, leaving the possibility that victims may not obtain full compensation of damages.

A third source of uncertainty for claimants arises because defendants may raise the passing-on defence. If the claimant is not a final consumer, the defendant may argue that the claimant passed on (part of) the higher prices down the supply chain to its own customers, and therefore did not suffer harm. This, again, requires a calculation of what would have been the competitive price, and an estimate by the court of which share of the overcharge was passed on.

Finally, various elements of evaluating evidence and proving losses still rely on national rules and procedures, as the Directive does not cover them. ${ }^{14}$ These rules and procedures may not be equally effective and efficient for claimants across all Member States. Moreover, claimants may not have the same possibilities for timely and affordable access to courts throughout the EU.

In sum, despite the stronger legal position of the victim under the Directive, victims still face procedural and practical obstacles. Given these specific circumstances in antitrust litigation, it appears reasonable to consider the possibility that victims may obtain only partial compensation for their losses resulting from the cartel infringement.

\section{LITERATURE}

Since our paper builds on the economic literature on enforcement, leniency policy and damages actions, this section presents a concise overview of this literature.

Public enforcement is often analyzed using Becker's economic approach to crime and punishment. ${ }^{15}$ Public enforcement of competition law leads to an expected sanction for members of a cartel. If the probability of detection and the fine lead to an expected sanction that exceeds the cartel profit, the formation or continuation of a cartel will be deterred. In practice, the probability of detection is believed to be relatively low. ${ }^{16}$ This means that, even with high sanctions, public enforcement of competition law may not prevent the formation of cartels. ${ }^{17}$

Leniency programs may strengthen public enforcement by destabilizing cartels and by helping to provide competition authorities with the necessary information to sanction cartels. Leniency programs may generate incentives to reveal information. This is accomplished by rewarding parties that reveal information that proves the existence of a cartel. The performance of leniency programs has been discussed extensively in the law

\footnotetext{
Article 6 of the Directive.

Article 17 of the Directive.

4 For instance, Article 12(5) of the Directive states that the courts shall estimate the share of overcharge that was passed-on according to national procedures. The rules and case law regarding evidence may differ across Member States.

15 Gary S. Becker, Crime and punishment: An economic approach, 76 J POL ECON 169 (1968).

16 Combe et al. estimate the annual probability that a cartel will be detected to be $12.9-13.3 \%$ based on all cartels convicted by the European Commission between 1969 and 2008. Emmanuel Combe et al., Cartels: The Probability of Getting Caught in the European Union. BRUGES EUR ECON RESEARCH PAPERS 12 (2008). https://www.coleurope.eu/system/files force/researchpaper/beer12.pdf?download=1. Older studies, such as Peter G. Bryant \& E. Woodrow Eckard, Price fixing: the probability of getting caught, 73 REV ECON STAT 3 (1991), find probabilities ranging from 13-17\%.

17 In the EU, sanctions are typically related to turnover of the firms, which is not directly related to a deterrence effect, so that on balance sanction times probability is also typically not related to the gains of a cartel.
} 
and economics literature. ${ }^{18}$ Motta and Polo employ a dynamic model in which firms may apply for leniency after an investigation has started. ${ }^{19}$ This model is in the spirit of a plea bargaining model, since parties are incentivized to disclose information proving illegal behavior. ${ }^{20}$ Motta and Polo demonstrate that a leniency program may have two possible effects. The positive effect is that it might lead firms to desist ex-post from colluding frequently. There may also be a perverse effect. Since a leniency program allows colluding firms to pay reduced fines, it may have ex-ante a pro-collusive effect, given that it decreases the expected costs of anticompetitive behavior. Spagnolo presents a dynamic model in which firms may apply for leniency before an investigation has started. ${ }^{21}$ This model is in the spirit of Becker's economic approach to crime and punishment. ${ }^{22}$ According to Spagnolo, the first best outcome (complete deterrence without inspection/prosecution costs) can be achieved with high enough finite fines by promising the first wrongdoer that applies for leniency and self-reports a sufficiently high "fines financed" reward. ${ }^{23}$

The interplay of leniency programs and damages actions is discussed in a number of recent papers. The main conclusion is that damages may reduce the incentive to apply for leniency. The incentive to apply for leniency originates from a reduction in the sanction. However, when the cartel is revealed, customers learn about its existence, and may file follow-on damages actions against the leniency applicant. In effect, the leniency applicant thus introduces its own damages liability, since customers usually would not have been aware of the cartel if the leniency applicant had not revealed it. Consequently, the possibility of follow-on damages may undermine leniency programs.

Spagnolo analyzes the influence of damages in the context of a dynamic model that also includes the decision to enter or continue a cartel. ${ }^{24}$ He finds that leniency programs that only exempt self-reporting firms from fines, and not from damages, are inefficient from a deterrence perspective. He notes that fine reductions must be increased to compensate for any expected damage payments, in order to maintain the incentive to apply for leniency in the presence of private antitrust enforcement. Buccirossi, Marvão and Spagnolo analyze a number of regimes combining leniency and damages. ${ }^{25}$ They focus on regimes from the EU, the US and Hungary. In the $\mathrm{EU}$, a successful leniency application will only result in immunity or a reduction of fines; it will not protect the leniency applicant from civil law consequences of his participation in a cartel. In the US, civil liability of leniency applicants is limited to single damages, whereas the other cartel participants may face punitive damages ("treble damages"). Moreover, US leniency applicants are only liable for the harm related to their own sales, while others are jointly and severally liable for the entire harm of the cartel (without the possibility to sue others for contribution). The Hungarian regime that applied before the Directive was introduced, limited the immunity recipient's liability to a "last resort" solution: the immunity recipient only had to reimburse damages insofar the claim could not be collected from the other cartel participants. Buccirossi, Marvão and Spagnolo conclude that the Hungarian regime performs better in terms of deterrence than the regimes from the EU and the US.

Silbye, as well as Kirst and Van den Bergh, present static game theoretic models to analyze the implications of damages actions on incentives to apply for leniency. ${ }^{26}$ They do not consider the decision of firms

18 Seminal papers in the field are Massimo Motta \& Michele Polo, Leniency programs and cartel prosecution, 21 INT J IND ORG 347 349 (2003), and Giancarlo Spagnolo, Divide et impera: Optimal leniency program,. Stockholm School of Economics (2005). Extensive overviews of the literature on the economic analysis of leniency programs can be found in Ulrich Blum et al., On the rationale of leniency programs: a game-theoretical analysis, 25 EUR J L \& ECON 209 (2008) and Giancarlo Spagnolo, Leniency and whistleblowers in antitrust, in HANDBOOK OF ANTITRUST ECONOMICS (Paolo Buccirossi ed. 2008) at 264. See also: Karine Brisset \& Lionel Thomas, Leniency program: A new tool in competition policy to deter cartel activity in procurement auctions, 17 EUR J L \& ECON 5 (2004); Paolo Buccirossi \& Giancarlo Spagnolo, Leniency policies and illegal transactions, 90 J PUBLIC ECON 1281 (2006); Joe Chen \& Joseph E. Harrington, The impact of the corporate leniency program on cartel formation and the cartel price path, THE POLITICAL ECONOMY OF ANTITRUST (Vivek Ghosal \& Johan Stennek eds, Amsterdam Elsevier, 2007).; Joseph E. Harrington, Optimal corporate leniency programs, 56 J INDUSTRIAL ECON 215 (2008).

19 Motta \& Polo supra note 18.

20 Spagnolo 2008 supra note 18 at 271.

21 Giancarlo Spagnolo, Optimal leniency programs, NOTA DI LAVORO 42.2000. Milan: Fondazione Eni Enrico Mattei (2000). See also Spagnolo 2005, supra note 18.

Becker 1968 supra note 15.

Spagnolo 2008, supra note 18 at 277.

Spagnolo 2005, supra note 18.

Paolo Buccirossi, Catarina Marvão \& Giancarlo Spagnolo, LENIENCY AND DAMAGES 2015. Available at SSRN 2566774.

Frederik Silbye, A note on antitrust damages and leniency programs, Eur J Law Econ 33 (2012), and Philipp Kirst \& Roger Van den Bergh, The European directive on damages actions: A missed opportunity to reconcile compensation of victims and leniency incentives, J COMPETITION L \& ECON, 1 (2016). 
to enter into a cartel. Silbye finds that liability for damages may lower incentives to apply for leniency, unless antitrust authorities are allowed to reward whistle-blowers. Kirst and Van den Bergh consider that applying for leniency may lead to the disclosure of information that may be used in damages actions. A high probability of disclosure tends to discourage applying for leniency. To encourage applying for leniency, Kirst and Van den Bergh suggest an alternative solution: a rule which grants immunity or reduction in damages in the same proportion as fines are waived or reduced under the leniency program.

The literature on the interplay of leniency and damages thus comprises static, one-period models and dynamic models with an infinite number of periods. We also develop a dynamic model, in order to capture not only the implications of damages on leniency, but also on cartel dynamics. It is, however, not necessary to turn to an infinite number of periods. That would be the case if a finite number of periods leads to unravelling, which is not the case in the model presented in the next section. Specific for our model is that we consider the possibility of partial compensation, depending on the legal position of the victim. For illustrative purposes we show simulation results for the two-period model. ${ }^{27}$ These simulations illustrate, inter alia, the implications for decisions whether or not to enter into a cartel, whether or not to apply for leniency, and for consumer welfare.

\section{CARTELISTS’ BEHAVIOR}

\section{A. Central assumptions}

Consider a "textbook cartel" that acts as a profit maximizing monopoly. Marginal costs are constant, $c$ and market demand is represented by a linear demand curve. This situation is depicted in figure 1 . The monopoly price is $p^{M}$ and the monopoly quantity is $q^{M}$. The monopoly price exceeds marginal costs. The so-called overcharge is equal to $m=\left(p^{M}-c\right) / p^{M}{ }^{28}$ The cartel's turnover is $O=p^{M} q^{M}$. Then, the cartel's profit can be written as $m O$.

Assume there is no pass-on of harm, that is: customers are consumers. ${ }^{29}$ In that case, the harm suffered by customers is equal to the extent that the price is increased by the cartel. Assuming that in the absence of a cartel there would be perfect competition, the competitive price $p^{C}$ would be equal to marginal costs $c$. Then, the harm the cartel inflicts on customers is equal to the cartel's profit, i.e. equal to $\mathrm{mO}$.

Cartel damages in damages litigation are typically defined as the distributional effects of the cartel. A deadweight loss may also be considered as damages. This is, in fact, a loss suffered by customers that would have bought the good if the market price had been equal to the marginal costs, but that did not make a purchase at the monopoly price. The dead weight loss in figure 1 is equal to $0.5 \mathrm{mO}$. The existence of a deadweight loss is, however, harder to prove in practice. We will therefore only consider the distributional damages.

To investigate whether parties will form a cartel and, if so, whether firms will apply for leniency we consider the following situation. Two identical firms with constant marginal cost consider the formation of a cartel. If a cartel is formed, after the first period of the cartel's existence a firm may consider applying for leniency. If no firm applies for leniency, the firms face a probability $P$ that the cartel will be detected by the competition authority. If the cartel is detected, then both firms will have to pay a fine $F .{ }^{30}$ If one of the firms

We also made simulations for the three-period model. Since this yields hardly any new insights in the impact of an improvement in the position of victims, we do not include these simulations in the paper.

28 See e.g. Practical Guide Quantifying Harm in Actions for Damages Based on Breaches of Article 101 or 102 of the Treaty on the Functioning of the European Union (http://ec.europa.eu/competition/antitrust/actionsdamages/quantification_guide_en.pdf), p. 128.

29 If not, some pass-on may be expected.

30 The fine $F$ is assumed to be independent of duration and turnover or damages. In general this will not be true: maximum fines are related to turnover and duration also influences fines, see also footnote 45 below. This may be captured in our model by including a parameter related to turnover that affects $F$. A possible extension of our model could consider the impact of such changes in the fine. 
applies for leniency, this firm is exempted from paying a fine whereas the other firm has to pay the full fine. If both firms apply for leniency, they expect to pay a fine of $1 / 2 \mathrm{~F}$. ${ }^{31}$

Figure 1. Loss resulting from the cartel price rise

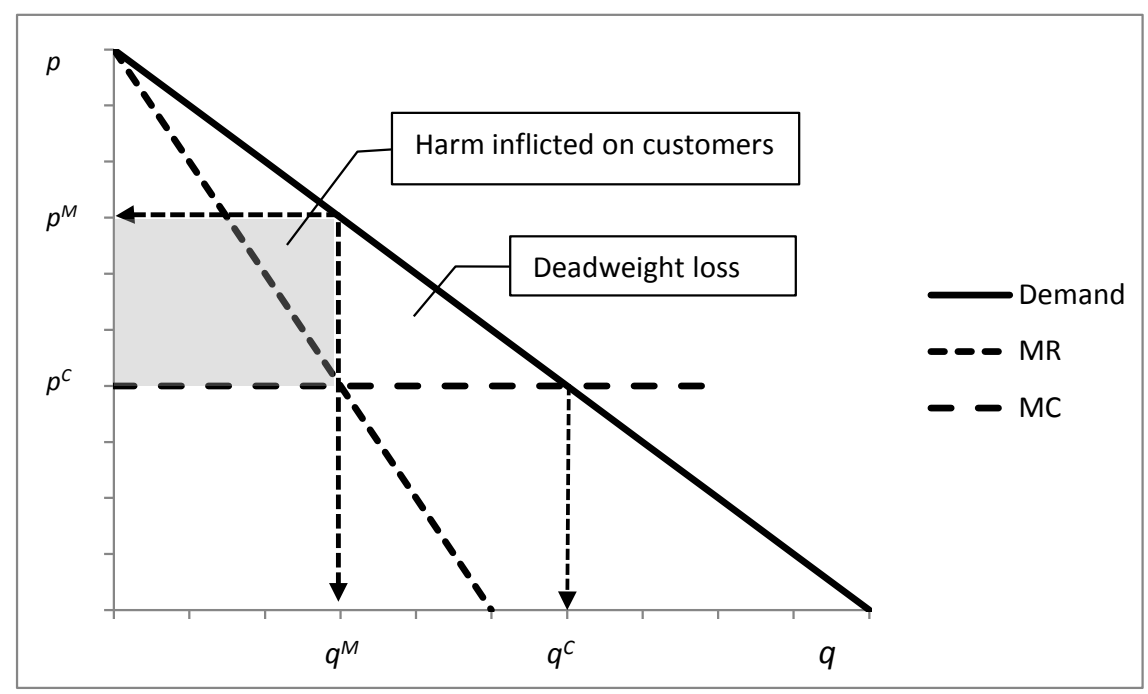

Customers of the cartel may claim damages. In principle, they may claim full compensation, i.e. damages equal to the overcharge. In practice, the position of victims may be such that they will receive less than full compensation. $^{32}$ The strength of the victims' position is given by $r$. The strength of the victims' position $r$ determines the degree to which harm will be compensated. $Y=0$ if the victim is unable to get any compensation and $Y=1$ if the victim is able to get full compensation. Generally, it will be the case that $0 \leq \Upsilon \leq 1 .^{33}$

Regarding the relation between public and private enforcement, we assume that there will only be follow-on claims. That is: if public enforcement proves the existence of the cartel, victims may use this information as a basis for claiming damages. Otherwise, victims will not be able to get any compensation. This assumption reflects the current reality of damages compensation since the vast majority of the larger antitrust civil damages claims in the EU are follow-on claims. ${ }^{34}$

\section{B. Timing}

In order to investigate dynamic aspects, we use a two-period model. The decisions the firms face in each period are depicted in the game tree in figure 2. Of course, the figure is a simplified representation of the complex decisions that firms have to make in practice. Such a simplified representation is necessary for analytical purposes. The left-hand-side of this figure regards period 1 ; the right-hand-side regards period 2 . In period 1 , firm 1 and 2 first have to decide whether they will form a cartel. ${ }^{35}$ There will be no cartel unless both decide to enter in a cartel. If both firms enter the cartel, the next decision of the firms that the model considers is whether they will apply for leniency after the first period. If at least one firm applies for leniency, the cartel will be

31 The EU leniency program offers first leniency applicants (the so-called "immunity applicant") full immunity from the fine, while second and later applicants may obtain reductions to the fine if they can offer additional evidence (Leniency Notice 2006, paragraphs. 8 e.f. and 23 e.f.). In this model, it is assumed that the first applicant already hands over sufficient evidence for the competition authority to sanction the cartel, meaning that the second applicant can no longer obtain a fine reduction. Upon expectation, therefore, each firm pays $1 / 2 \mathrm{~F}$ in the case that both firms apply for leniency.

32 We assume that victims effectively act as one victim, for instance because there is an effective claim organization that represents the victim. In the absence of any organization of the victims, victims may not be in a position to claim compensation.

$33 \quad \Upsilon>1$ would represent punitive damages, but we do not consider this case. Article 3(3) of the Directive states that: "Full compensation under this Directive shall not lead to overcompensation, whether by means of punitive, multiple or other types of damages.”

34 Matthijs Kuijpers et al., Actions for Damages in the Netherlands, the United Kingdom and Germany, 6 J EUR COMPETITION L \& PRACTICE, 129, 130 (2015).

35 Firms decide independently whether or not to enter the cartel. If the firms form a cartel, this implies that they raise the price, leading to a reduced output. 
revealed. If the cartel is revealed in period 1 , we assume that there will be no cartel in period $2 .{ }^{36}$ If neither firm applies for leniency, there is a probability that the cartel will be detected by the competition authority. If the cartel is not detected, the game proceeds to period 2. Consequently, if firms form a cartel and do not apply for leniency in period 1 , there is a probability that they are not caught by the competition authority and realize a profit in period 2. Assuming the firms are rational, in making decisions in period 1 they will anticipate what can be expected to happen in period 2. Therefore, the decision in period 1 will depend on the expected pay-off in period 2. In period 2, the firms have to make essentially the same decisions: to enter in cartel and, if so, to apply for leniency or not. The decisions in period 1 thus depend on the decisions in period 2. The game may, in other words, be solved using backward-induction.

Figure 2. Game tree

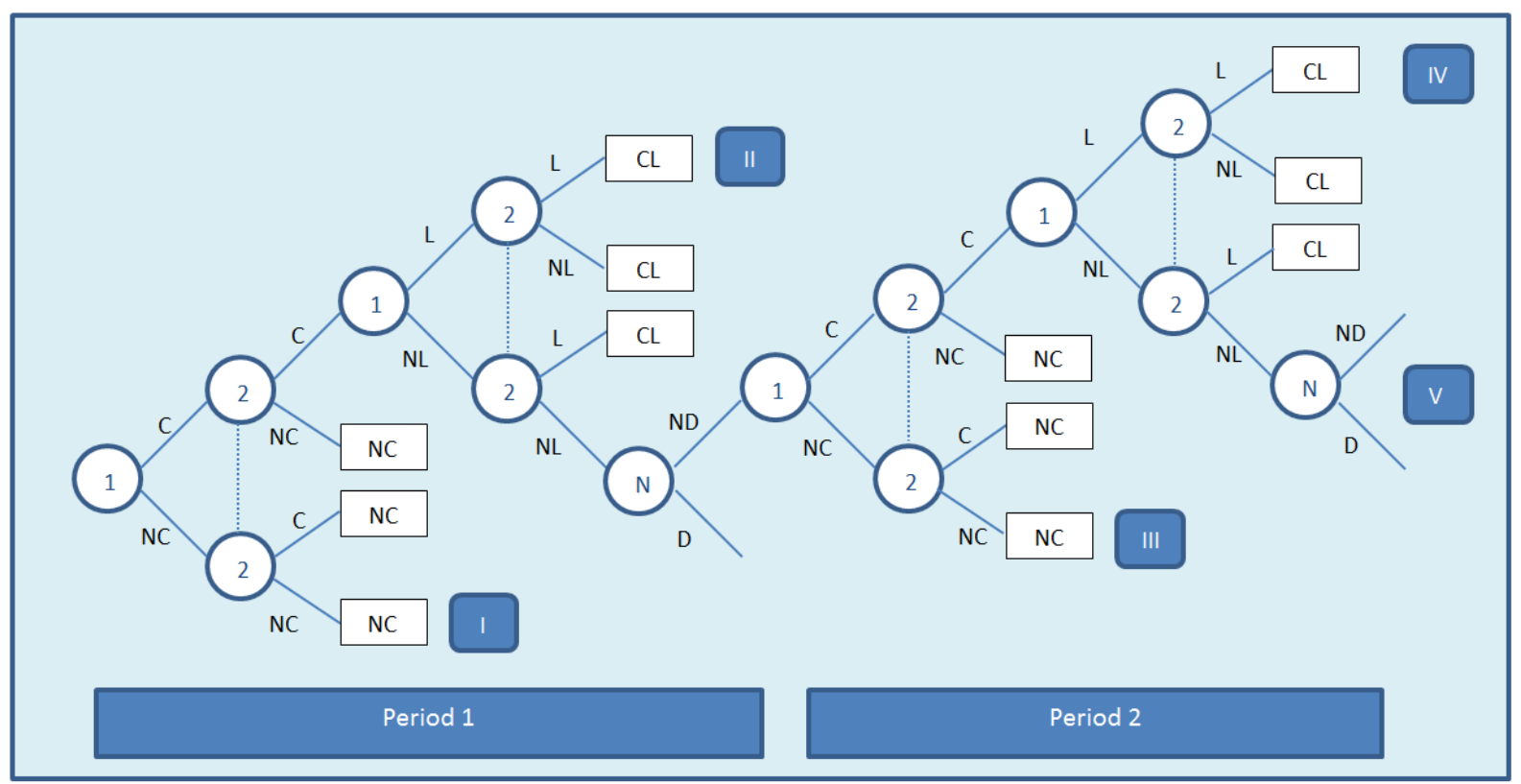

\section{Pay-off matrices}

Based on the assumptions formulated in the preceding section, we now present the pay-off matrices for both periods. ${ }^{37}$ These matrices depict the pay-offs for both firms, depending on the choices both make. The matrices provide the basis for analyzing choices. More specifically, they enable investigating the firms' behavior in a situation where private damages actions and leniency programs may interfere. This section presents the pay-off matrices in general terms. In the next section, the matrices will be used as a basis for building a simulation model.

If a cartel is formed, it will exist during one period after which all the other decisions may take place. If neither firm applied for leniency and the cartel remains otherwise undetected, the cartel may be continued for the second period. Similarly, if the cartel survives the second period, the same type of decisions may again be made and the game ends.

\footnotetext{
36 As in other papers, such as Motta \& Polo supra note 18, we assume firms have no possibility to return to collusion in the period after the cartel has been revealed under the leniency program or discovery by the competition authority. During this period, the competition authority is able to impose compliance on the firms and prevent them from entering into a cartel. Other than in Motta \& Polo, however, this paper does not distinguish a separate investigation stage of the competition authority: both reporting by a cartel member and detection by the competition authority lead to a fine with certainty.

37 The two cartel members are strictly symmetric and consequently all revenues, profits and damages payments may be assumed to be divided by 2 , so that we need not do this in our calculations.
} 
If parties did not apply for leniency in period 1 and if the cartel is not caught by the competition authority, the firms may decide not to continue the cartel in period 2. For this case, we assume that the period 1 cartel will not be detected retrospectively in period 2. That is, we assume for this case that the game ends after period $1 .^{38}$

\section{1. $\quad$ Period 2}

We first consider period 2 since the decisions in period 1 will be influenced by the pay-off that can be expected in period 2. If both firms apply for leniency, a firm's pay-off in this case consists of three elements: cartel profit $(\mathrm{mO})$, a reduced fine because both firms apply for leniency $(1 / 2 \mathrm{~F})$ and the payment of a (partial) compensation to the victims for harm suffered in period 1 and $2(2 \gamma \mathrm{mO})$. If only one firm applies for leniency, this firm is exempted from paying a fine but the other firm has to pay the full fine and both will pay damages. If no firm applies for leniency, a firm in this case obtains a profit and faces a probability $P$ that the cartel will be detected. If the cartel is detected, a firm has to pay a fine $F$ and has to pay compensation to the victim based on damages inflicted in both periods. Table 1 depicts the pay-off matrix for period 2.

Table 1. Pay-off matrix period 2

\begin{tabular}{ccccc}
\hline \multirow{2}{*}{ Firm 1 } & \multicolumn{3}{c}{ Firm 2 } \\
\cline { 2 - 4 } Leniency & $m O-1 / 2 F-2 \Upsilon m O$ & $m O-2 \Upsilon m O$ & No leniency \\
No leniency & $m O-F-2 \Upsilon m O$ & $m O-1 / 2 F-2 \Upsilon m O$ & & $m O-F-2 \Upsilon m O$ \\
& & $m O-2 \Upsilon m O$ & $m O-P(F+2 \Upsilon m O)$ & $m O-P(F+2 \Upsilon m O)$ \\
\hline
\end{tabular}

The situation where both cartelists apply for leniency, denoted by ( $\mathrm{L}, \mathrm{L})$, is a Nash-equilibrium. That is, no party has an incentive to unilaterally change its behavior, since changing its behavior would lead to a lower pay-off. ${ }^{39}$ The intuition is straightforward: Starting in the situation where both parties apply for leniency, the decision of a firm not to apply for leniency would only result in an increase in the fine the firm has to pay. The situation where both cartelists do not apply for leniency, indicated (NL,NL), may also be a Nash-equilibrium. This is the case if the probability of detection is "low enough". ${ }^{40}$ If $(\mathrm{NL}, \mathrm{NL})$ is a Nash-equilibrium this equilibrium is pay-off dominant, that is: both parties are better-off if they do not apply for leniency compared to the situation where both parties do apply for leniency. ${ }^{41}$

Effectively, this assumption means that there is a time limit for victims to file their claims for damages. Because $m O-1 / 2 F-2 Y m O>m O-F-2 Y m O$.

40 (NL,NL) is also a Nash-equilibrium if $m O-P(F+2 \Upsilon m O) \geq m O-2 \Upsilon m O$, that is if $P \leq \frac{2 \gamma m o}{F+2 \curlyvee m o}$.

41 Because being a Nash-equilibrium requires $m O-P(F+2 \Upsilon m O) \geq m O-2 \Upsilon m O$, which implies: $m O-P(F+2 Y m O) \geq m O-1 / 2 F-2 Y m O$. 


\section{Period 1}

Now consider period 1. If both firms apply for leniency, the pay-offs for both firms will be equal to $m O-1 / 2 F-$ YmO. A firm's pay-off in this case consists of three elements: cartel profit, a reduced fine because both firms apply for leniency and the payment of a (partial) compensation to the victims. If only one firm applies for leniency, this firm is exempted from paying a fine but the other firm has to pay the full fine (and both have to pay damages). If no firm applies for leniency, a firm has a profit in the first period and, if the cartel is not detected (with probability $1-P$ ) an expected profit in period 2 denoted by $Z$. If the firm is detected (probability $P$ ), the firm has to pay a fine $(F)$ and a (partial) compensation to the victims based on damages inflected in period $1(\Upsilon \mathrm{mO})$. Table 2 depicts the pay-off matrix for period 1 .

The situation where both parties apply for leniency is a Nash-equilibrium in period $1 .^{42}$ (NL,NL) may also be a Nash-equilibrium. This is the case if $P$ is low enough. ${ }^{43}$ If (NL,NL) is a Nash-equilibrium, this equilibrium is pay-off dominant and the pay-off must be positive. ${ }^{44}$

Table 2. Pay-off matrix period 1

\begin{tabular}{ccccc}
\hline \multirow{2}{*}{ Firm 1 } & \multicolumn{3}{c}{ Firm 2 } \\
\cline { 2 - 4 } Leniency & $m O-1 / 2 F-\Upsilon m O$ & \multicolumn{2}{c}{ No leniency } \\
No leniency & $m O-F-\Upsilon m O$ & $m O-1 / 2 F-\Upsilon m O$ & $m O-\Upsilon m O$ & $m O-F-\Upsilon m O$ \\
& & $m O-\Upsilon m O$ & $m O+(1-P) Z-P(F+\Upsilon m O)$ & $m O+(1-P) Z-P(F+\Upsilon m O)$ \\
\hline
\end{tabular}

Where $Z$ = expected pay-off period 2

The pay-off matrices provide the basis for analyzing the firms' behavior in a situation where leniency programs and private damages actions may interfere. This can be done by inserting information on cartel profit, fines, the probability of detection and the victims' legal position.

This is because $m O-1 / 2 F-\gamma m O>m O-F-Y m O$.

(NL,NL) is a Nash-equilibrium in period 1 if $m O+(1-P) Z-P(F+Y m O) \geq m O-Y m O$.

4 Because $m O-\Upsilon m O \geq 0$ and $m O-\Upsilon m O>m O-1 / 2 F-\Upsilon m O$. 


\section{Example}

Consider the case with cartel profit $m O=10$, fine $F=5$, probability of detection $P=0.5$, and the victims' legal position $\Upsilon=0.8$. Filling in these values in the period 2 pay-off matrix shows that (NL,NL) is an equilibrium in period 2 , since $-0.5>-6$. This equilibrium is pay-off dominant, since $-0.5>-8.5$. Because the pay-off is negative, there will be no cartel in period 2 .

Pay-off matrix period 2

\begin{tabular}{cccccc}
\hline \multirow{2}{*}{ Firm 1 } & & \multicolumn{4}{c}{ Firm 2 } \\
\cline { 3 - 5 } & Leniency & \multicolumn{2}{c}{ Leniency } & \multicolumn{2}{c}{ No leniency } \\
\cline { 3 - 5 } & \multirow{2}{*}{ No leniency } & -11 & -8.5 & -6 & -11 \\
& & & -6 & -0.5 & -0.5 \\
\hline
\end{tabular}

Next, we turn to period 1. Filling in the values of $m O, F, P$, and $\Upsilon$ and accounting for the fact that the pay-off in period 2 will be zero, yields the period 1 pay-off matrix. (NL,NL) is an equilibrium in period 1 , since $3.5>2$. This equilibrium is pay-off dominant, since $3.5>-0.5$. Because the pay-off is positive, there will be a cartel in period 1.

\begin{tabular}{cccccc}
\multicolumn{2}{c}{ Pay-off matrix period 1 } & \multicolumn{4}{c}{ Firm 2 } \\
\cline { 3 - 6 } Firm 1 & & \multicolumn{2}{c}{ Leniency } & No leniency \\
\hline & Leniency & -0.5 & -0.5 & 2 & -3 \\
& No leniency & -3 & 2 & 3.5 & 3.5 \\
\hline
\end{tabular}

In summary: if $m O=10, F=5, P=0.5$ and $\Upsilon=0.8$, in period 1 the parties will enter into a cartel and they will not apply for leniency and in period 2 they will not continue the cartel. In terms of figure 2: the outcome is in category III.

\section{SIMULATION RESULTS}

From the outcome matrices it is clear that the outcomes in period 1 and 2 depend on the harm inflicted on consumers $(m O)$, the probability of detection $(P)$, the victims' position $(Y)$ and the fine $(F)$. We are especially interested in the impact of an improvement in the victims' position - that is, an increase in compensation of the victim's harm. It appears to be impossible to find a convenient analytical expression of the impact of an improvement in the victims' position on cartelists' behavior. Therefore, in this section we first present the outcomes of simulations. These simulations show the potential outcomes in both periods. Next, we compute the consumers' expected net loss associated with the outcomes. Based on that, we evaluate the implications of an improvement of the victims' position for whether firms apply for leniency, for whether they decide to enter into a cartel, and for consumer welfare.

\section{A. Example}

We consider a case in which the cartel profit $m O$ is equal to $10(m=0.1$ and $O=100)$. The harm inflicted on customers is equal to the cartel profit, i.e. 10. Regarding the probability of detection $P$ we consider all values from 0 to 1 , increasing by increments of 0.1 . With respect to the victims' position $Y$ we consider all values from 0 to 1 , increasing by increments of 0.1 . Based on these points, we consider $121 P$ - $Y$-combinations. Furthermore, we consider fines between 0 and 10 . A fine equal to 10 would effectively be a fine equal to $10 \%$ over cartel turnover. This can be considered a maximum fine. ${ }^{45}$ Table 3 presents the data.

45 For each undertaking and association of undertakings participating in the infringement, the fine shall not exceed $10 \%$ of its total turnover in the preceding business year. Source: Article 23 of COUNCIL REGULATION (EC) No 1/2003 of 16 December 2002 on the 
Table 3. Data used in the example

\begin{tabular}{lll}
\hline & & Values \\
\hline Harm inflicted on customers & $m O$ & 10 \\
Probability of detection & $P$ & $0,0.1,0.2, \ldots, 1$ \\
Victims' position & $r$ & $0,0.1,0.2, \ldots, 1$ \\
Fine & $F$ & $0,2.5,5,10$ \\
\hline
\end{tabular}

In order to examine the influence of $P, Y$ and $F$, we proceed as follows. First, we consider period 2 . We determine whether (L,L) or (NL,NL) will be the (pay-off dominant) Nash-equilibrium and what the pay-offs will be. In case of a negative pay-off, there will be no cartel in period 2 (and the expected pay-off in period 1 and 2 will in fact be zero). The choice whether or not to form a cartel in period 2 and, if so, whether or not to apply for leniency, will be called the outcome in period 2. Next, we turn to period 1. Given the outcome in period 2, we will determine the (pay-off dominant) Nash-equilibrium in period 1 . The choice whether or not to form a cartel in period 1 and, if so, whether or not to apply for leniency, will be called the outcome in period 1 . We can simply fill-in the numbers from the example in the pay-off matrices and compute the outcomes in both periods.

\section{B. Potential outcomes}

Computing the outcomes in both periods, based on the procedure explained above, leads to the overall possible outcomes as presented in Table 4.

Table 4. Potential outcomes

\begin{tabular}{lcc}
\hline & Period 1 & Period 2 \\
\hline $\mathbf{1}$ & No cartel & No cartel \\
$\mathbf{2}$ & Leniency & No cartel \\
$\mathbf{3}$ & No leniency & No cartel \\
$\mathbf{4}$ & No leniency & Leniency \\
$\mathbf{5}$ & No leniency & No leniency \\
\hline
\end{tabular}

Figure 3 presents the outcomes of the simulations. Figure 3 a. presents the outcomes for a fine equal to 0 . The horizontal axis shows different values of $Y$. The minimum value is 0 , increments are 0.1 and the maximum value is 1 . The vertical axis shows different values of $P$. The minimum value is 0 , increments are 0.1 and the maximum value is 1 . 
Figure 3. Outcomes (two-period model)

a. $F=0$

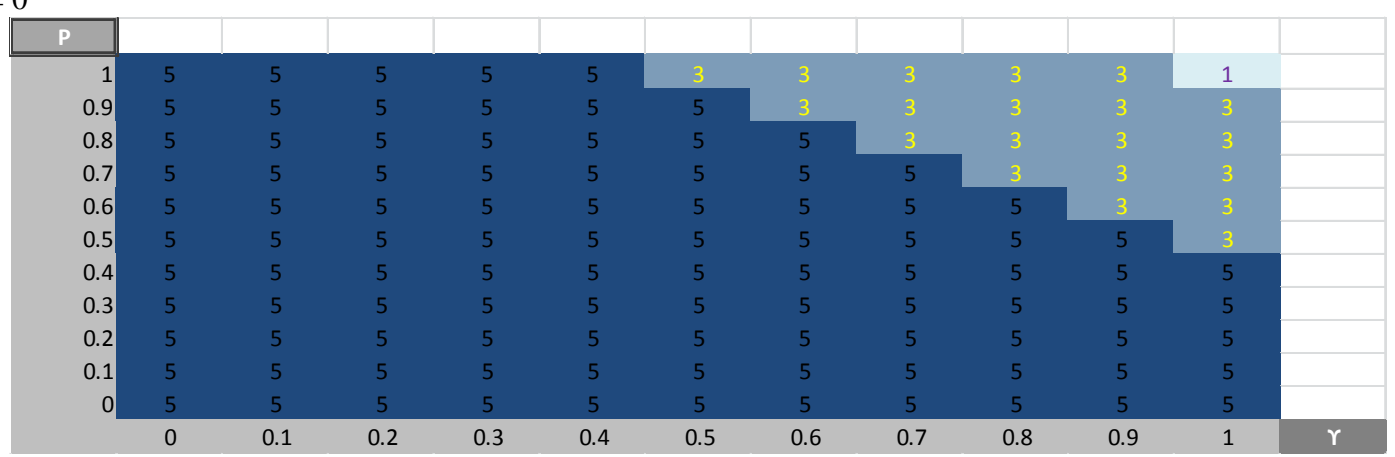

b. $F=2.5$

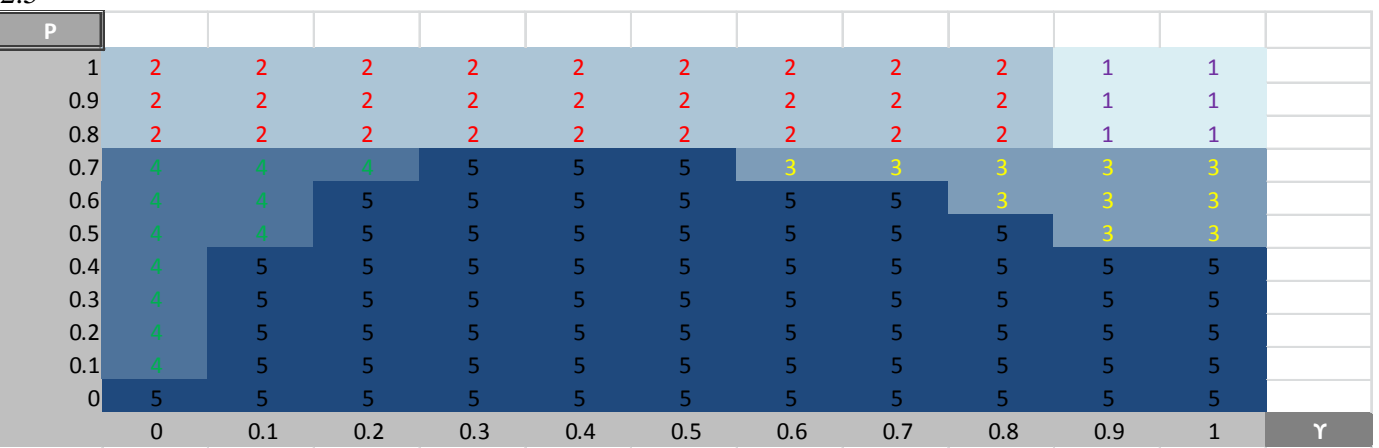

c. $F=5$

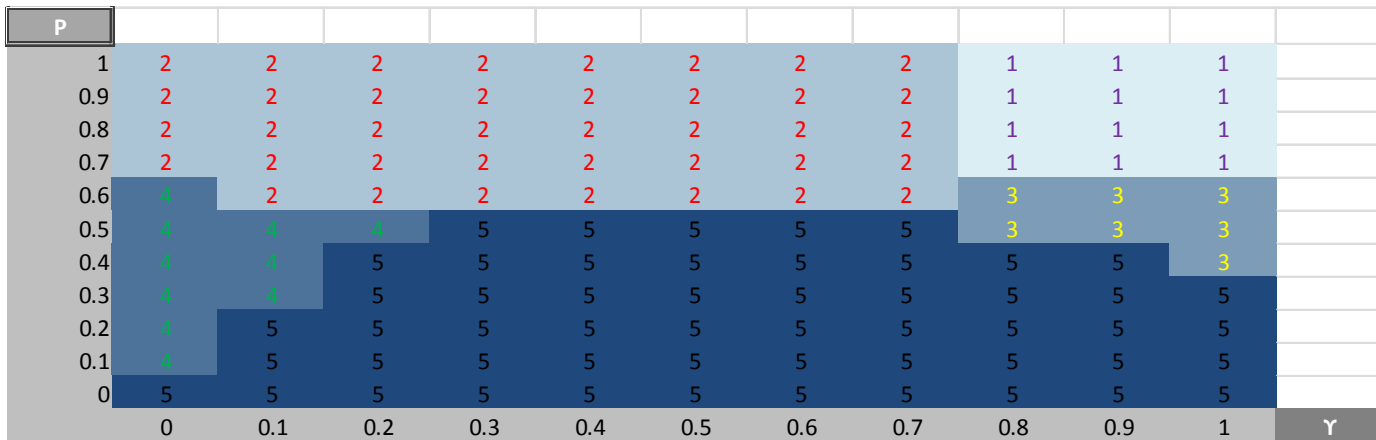

d. $F=10$

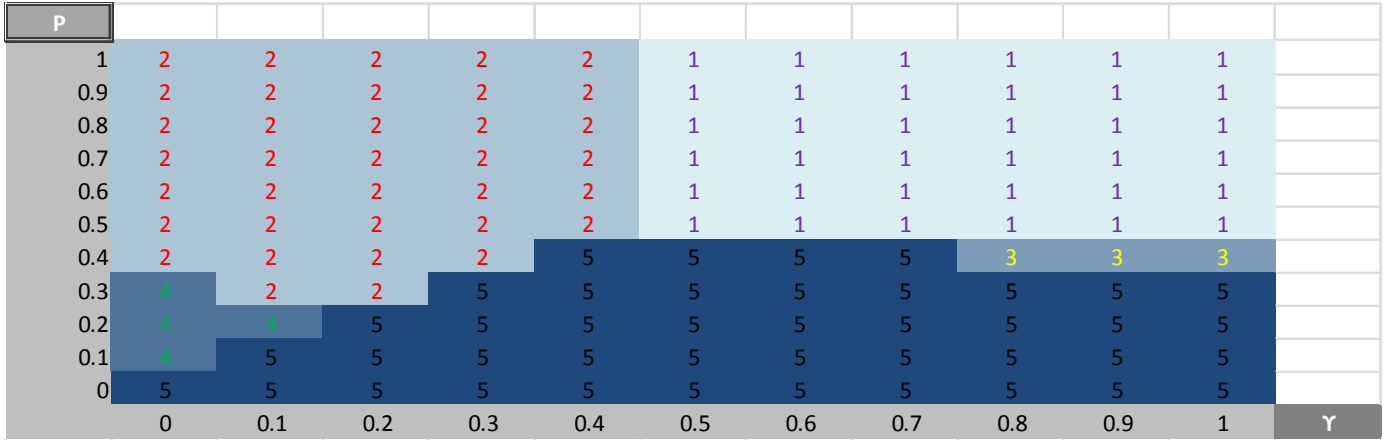

Legend

\begin{tabular}{|c|c|c|}
\hline & Period 1 & Period 2 \\
\hline 1 & No cartel & No cartel \\
\hline 2 & Leniency & No cartel \\
\hline 3 & No leniency & No cartel \\
\hline 5 & No leniency & Leniency \\
\hline & No leniency & No leniency \\
\hline
\end{tabular}


In the hypothetical case with a fine equal to zero (Figure 3.a), the cartel will only be deterred in both periods if the probability of detection is equal to one and the position of the victim is such that he can effectively claim full compensation (denoted by ' 1 '). The intuition is straightforward. Entering a cartel yields a profit. But if the probability of detection is 1 and victims can effectively claim full-compensation, on balance forming a cartel yields no profit.

However if the position of victims is weaker $(\Upsilon<1)$ or the probability of detection lower than 1 , forming a cartel may be profitable. If $P=1$ there will be a cartel in the first period, but the cartel in period 2 will be deterred if victims can effectively claim damages of at least $50 \%$ of harm $(0.5<\Upsilon<1)$. More generally, for values of $P$ or $Y$ smaller than 1, there will be a cartel in period 1 and the firms will not apply for leniency. For relatively high values of $P$ and $Y$ the firms will decide not to enter in a cartel in period 2 . This is caused by the fact that profit in period 2 is smaller than the expected damages for both periods. Clearly, if $P=1$ and $\Upsilon \geq 0.5$ there cannot be a period 2 cartel. The same applies for $\Upsilon=1$ and $P \geq 0.5$. Figure $3 \mathrm{~b}$. until 3 d. have similar interpretations. $^{46}$

\section{Partial compensation and consumer welfare}

Does an improvement in the legal positions of victims make consumers better off? Clearly, consumers would not suffer any harm if no cartel is formed in the first place. But, as demonstrated in the preceding section, this is just one of the potential outcomes. In the second potential outcome, there is only a cartel in period 1 and the members of the cartel apply for leniency. Consequently, consumers suffer harm $m O$ and they receive a partial compensation $Y \mathrm{mO}$. In the third potential outcome, there is only a cartel in period 1 and the members of the cartel do not apply for leniency. There is a probability $P$ that the cartel will be detected. Consequently, victims suffer harm $m O$ and the expected compensation is PYmO. In the fourth potential outcome, there is a cartel in period 1 and the members of the cartel do not apply for leniency. There is a probability $1-P$ that the cartel will not be detected. If the cartel is not detected in period 1, there will be a cartel in period 2 and the members of the cartel will apply for leniency. In the last potential outcome, there is a cartel in period 1 and the members of the cartel do not apply for leniency. There is a probability $1-P$ that the cartel will not be detected. If the cartel is not detected in period 1, there will be a cartel in period 2 and the members of the cartel will not apply for leniency. Consequently, in period 2 consumers will only receive partial compensation if the cartel is detected. Table 5 depicts the consumers expected net loss for the five potential outcomes.

Table 5. Consumer's expected net loss

\begin{tabular}{lccl}
\hline & Period 1 & Period $\mathbf{2}$ & Consumers' expected net loss \\
\hline $\mathbf{1}$ & $\mathrm{NC}$ & $\mathrm{NC}$ & 0 \\
$\mathbf{2}$ & $\mathrm{L}$ & $\mathrm{NC}$ & $m O-\Upsilon m O$ \\
$\mathbf{3}$ & $\mathrm{NL}$ & $\mathrm{NC}$ & $m O-P \Upsilon m O$ \\
$\mathbf{4}$ & $\mathrm{NL}$ & $\mathrm{L}$ & $m O-P Y m O+(1-P)(m O-\Upsilon m O)$ \\
$\mathbf{5}$ & $\mathrm{NL}$ & $\mathrm{NL}$ & $m O-P Y m O+(1-P)(m O-P \Upsilon m O)$ \\
\hline
\end{tabular}

To calculate the consumers' expected net loss, we first determine what the outcome will be in terms of the five potential outcomes (see figure 3) and, on that basis, we then compute the consumers' expected net loss using the formula shown above. Figure 4 presents the outcomes.

Consumers are best-off if the probability of detection is high and they have a very strong legal position. In that case the formation of a cartel is effectively deterred and the expected net loss will be zero. Consumers will be in the worst possible position if the probability of detection is zero. They will suffer harm in both periods and they will not receive any compensation (the expected net loss will be 20).

\footnotetext{
46 Note that the example presented in section IV is represented by a point in figure 3c where $P=0.5$ and $Y=0.8$ leading to a category 3 outcome: in period 1 the parties will enter into a cartel and they will not apply for leniency and in period 2 they will not continue the cartel.
} 
Figure 4. Consumers' expected net loss (two-period model)

a. $F=0$

\begin{tabular}{|c|c|c|c|c|c|c|c|c|c|c|c|c|}
\hline$P$ & & & & & & & & & & & & \\
\hline 1 & 10 & 9 & 8 & 7 & 6 & 5 & 4 & 3 & 2 & 1 & 0 & \\
\hline 0.9 & 11 & 10.01 & 9.02 & 8.03 & 7.04 & 6.05 & 4.6 & 3.7 & 2.8 & 1.9 & 1 & \\
\hline 0.8 & 12 & 11.04 & 10.08 & 9.12 & 8.16 & 7.2 & 6.24 & 4.4 & 3.6 & 2.8 & 2 & \\
\hline 0.7 & 13 & 12.09 & 11.18 & 10.27 & 9.36 & 8.45 & 7.54 & 6.63 & 4.4 & 3.7 & 3 & \\
\hline 0.6 & 14 & 13.16 & 12.32 & 11.48 & 10.64 & 9.8 & 8.96 & 8.12 & 7.28 & 4.6 & 4 & \\
\hline 0.5 & 15 & 14.25 & 13.5 & 12.75 & 12 & 11.25 & 10.5 & 9.75 & 9 & 8.25 & 5 & \\
\hline 0.4 & 16 & 15.36 & 14.72 & 14.08 & 13.44 & 12.8 & 12.16 & 11.52 & 10.88 & 10.24 & 9.6 & \\
\hline 0.3 & 17 & 16.49 & 15.98 & 15.47 & 14.96 & 14.45 & 13.94 & 13.43 & 12.92 & 12.41 & 11.9 & \\
\hline 0.2 & 18 & 17.64 & 17.28 & 16.92 & 16.56 & 16.2 & 15.84 & 15.48 & 15.12 & 14.76 & 14.4 & \\
\hline 0.1 & 19 & 18.81 & 18.62 & 18.43 & 18.24 & 18.05 & 17.86 & 17.67 & 17.48 & 17.29 & 17.1 & \\
\hline 0 & 20 & 20 & 20 & 20 & 20 & 20 & 20 & 20 & 20 & 20 & 20 & \\
\hline & 0 & 0.1 & 0.2 & 0.3 & 0.4 & 0.5 & 0.6 & 0.7 & 0.8 & 0.9 & 1 & $\gamma$ \\
\hline
\end{tabular}

b. $F=2.5$

\begin{tabular}{|r|c|c|c|c|c|c|c|c|c|c|c|c|}
\hline \multicolumn{1}{|r|}{$\mathbf{P}$} & & & & & & & & & & & \\
\hline \hline 1 & 10 & 9 & 8 & 7 & 6 & 5 & 4 & 3 & 2 & 0 & 0 & \\
0.9 & 10 & 9 & 8 & 7 & 6 & 5 & 4 & 3 & 2 & 0 & 0 & \\
0.8 & 10 & 9 & 8 & 7 & 6 & 5 & 4 & 3 & 2 & 0 & 0 & \\
0.7 & 13 & 12 & 11 & 10.27 & 9.36 & 8.45 & 5.8 & 5.1 & 4.4 & 3.7 & 3 & \\
0.6 & 14 & 13 & 12.32 & 11.48 & 10.64 & 9.8 & 8.96 & 8.12 & 5.2 & 4.6 & 4 & \\
0.5 & 15 & 14 & 13.5 & 12.75 & 12 & 11.25 & 10.5 & 9.75 & 9 & 5.5 & 5 & \\
0.4 & 16 & 15.36 & 14.72 & 14.08 & 13.44 & 12.8 & 12.16 & 11.52 & 10.88 & 10.24 & 9.6 & \\
0.3 & 17 & 16.49 & 15.98 & 15.47 & 14.96 & 14.45 & 13.94 & 13.43 & 12.92 & 12.41 & 11.9 & \\
0.2 & 18 & 17.64 & 17.28 & 16.92 & 16.56 & 16.2 & 15.84 & 15.48 & 15.12 & 14.76 & 14.4 & \\
0.1 & 19 & 18.81 & 18.62 & 18.43 & 18.24 & 18.05 & 17.86 & 17.67 & 17.48 & 17.29 & 17.1 & \\
0 & 20 & 20 & 20 & 20 & 20 & 20 & 20 & 20 & 20 & 20 & 20 & \\
& 0 & 0.1 & 0.2 & 0.3 & 0.4 & 0.5 & 0.6 & 0.7 & 0.8 & 0.9 & 1 & $\gamma$ \\
\hline
\end{tabular}

c. $F=5$

\begin{tabular}{|r|r|c|c|c|c|c|c|c|c|c|c|c|}
\hline \multicolumn{1}{|r|}{$\mathbf{P}$} & & & & & & & & & & & \\
\hline \hline 1 & 10 & 9 & 8 & 7 & 6 & 5 & 4 & 3 & 0 & 0 & 0 & \\
0.9 & 10 & 9 & 8 & 7 & 6 & 5 & 4 & 3 & 0 & 0 & 0 & \\
0.8 & 10 & 9 & 8 & 7 & 6 & 5 & 4 & 3 & 0 & 0 & 0 & \\
0.7 & 10 & 9 & 8 & 7 & 6 & 5 & 4 & 3 & 0 & 0 & 0 & \\
0.6 & 14 & 9 & 8 & 7 & 6 & 5 & 4 & 3 & 5.2 & 4.6 & 4 & \\
0.5 & 15 & 14 & 13 & 12.75 & 12 & 11.25 & 10.5 & 9.75 & 6 & 5.5 & 5 & \\
0.4 & 16 & 15 & 14.72 & 14.08 & 13.44 & 12.8 & 12.16 & 11.52 & 10.88 & 10.24 & 6 & \\
0.3 & 17 & 16 & 15.98 & 15.47 & 14.96 & 14.45 & 13.94 & 13.43 & 12.92 & 12.41 & 11.9 & \\
0.2 & 18 & 17.64 & 17.28 & 16.92 & 16.56 & 16.2 & 15.84 & 15.48 & 15.12 & 14.76 & 14.4 & \\
0.1 & 19 & 18.81 & 18.62 & 18.43 & 18.24 & 18.05 & 17.86 & 17.67 & 17.48 & 17.29 & 17.1 & \\
0 & 20 & 20 & 20 & 20 & 20 & 20 & 20 & 20 & 20 & 20 & 20 & \\
& 0 & 0.1 & 0.2 & 0.3 & 0.4 & 0.5 & 0.6 & 0.7 & 0.8 & 0.9 & 1 & $\gamma$ \\
\end{tabular}

d. $F=10$

\begin{tabular}{|r|c|c|c|c|c|c|c|c|c|c|c|c|}
\hline \hline$P$ & & & & & & & & & & & \\
\hline 1 & 10 & 9 & 8 & 7 & 6 & 0 & 0 & 0 & 0 & 0 & 0 & \\
0.9 & 10 & 9 & 8 & 7 & 6 & 0 & 0 & 0 & 0 & 0 & 0 & \\
0.8 & 10 & 9 & 8 & 7 & 6 & 0 & 0 & 0 & 0 & 0 & 0 & \\
0.7 & 10 & 9 & 8 & 7 & 6 & 0 & 0 & 0 & 0 & 0 & 0 & \\
0.6 & 10 & 9 & 8 & 7 & 6 & 0 & 0 & 0 & 0 & 0 & 0 & \\
0.5 & 10 & 9 & 8 & 7 & 6 & 0 & 0 & 0 & 0 & 0 & 0 & \\
0.4 & 10 & 9 & 8 & 7 & 13.44 & 12.8 & 12.16 & 11.52 & 6.8 & 6.4 & 6 & \\
0.3 & 17 & 9 & 8 & 15.47 & 14.96 & 14.45 & 13.94 & 13.43 & 12.92 & 12.41 & 11.9 & \\
0.2 & 18 & 17 & 17.28 & 16.92 & 16.56 & 16.2 & 15.84 & 15.48 & 15.12 & 14.76 & 14.4 & \\
0.1 & 19 & 18.81 & 18.62 & 18.43 & 18.24 & 18.05 & 17.86 & 17.67 & 17.48 & 17.29 & 17.1 & \\
0 & 20 & 20 & 20 & 20 & 20 & 20 & 20 & 20 & 20 & 20 & 20 & \\
& 0 & 0.1 & 0.2 & 0.3 & 0.4 & 0.5 & 0.6 & 0.7 & 0.8 & 0.9 & 1 & $\Upsilon$ \\
\end{tabular}




\section{The impact of an improvement in the position of victims}

From the previous section it is clear that the outcomes in period 1 and 2 depend on the harm inflicted on consumers $(m O)$, the probability of detection $(P)$, the victims' position $(Y)$ and the fine $(F)$. The probability of detection, the level of fines and the position of victims in private damages actions can be considered "policy variables". That is, policy-makers may try to manipulate these variables in order to influence firms' decisions. ${ }^{47}$ We are especially interested in the impact of an improvement in the victims' position.

We first concisely discuss the impact of an increase in the level of fines and the probability of detection. Next, we extensively discuss the impact of an improvement in the legal position of victims.

The impact of the level of fines can be seen from figure 3. In case of a fine equal to zero (figure 3a), there appears to be only one case in category 1 (no cartel in both periods), 20 cases in category 3 (cartel in period 1 only) and 100 cases on category 5 (cartel in both periods). By increasing the level of fines, the outcomes will change. This is summarized in table 6 . The table demonstrates that an increase in the level of fines has a deterrent effect. An increase in fine leads to an increase in the number of cases in which there will be no cartel in both periods, and a decrease in the number of cases in which there will be a cartel in both periods.

Table 6. The impact of the level of fines

\begin{tabular}{cccccc}
\hline Fine & Cat. 1 & Cat. 2 & Cat. 3 & Cat. 4 & Cat. 5 \\
NC | NC & L | NC & NL | NC & NL | L & NL | NL \\
\hline $\mathbf{0}$ & 1 & 0 & 20 & 0 & 100 \\
$\mathbf{2 . 5}$ & 6 & 27 & 10 & 10 & 67 \\
$\mathbf{5}$ & 12 & 39 & 7 & 4 & 53 \\
\hline
\end{tabular}

The impact of an increase in the probability of detection can be seen in figures 3 and 4 . A marginal increase in $P$ is represented by a small movement in an upward direction. As can be seen from figure 4, an increase in the probability of detection generally leads to a reduction in the victims' expected net loss. There are, however, two situations where an increase in the probability of detection has no influence on the victims' expected net loss. The first is where the formation of a cartel was already effectively deterred (category 1). In that case, the victims' expected net loss is zero. The second is where the cartelists apply for leniency in period 1 (category 2). In that case the victims' expected net loss is equal to $\mathrm{mO}-\mathrm{YmO}_{\mathrm{m}}$.

Since we are especially interested in the impact of a change in the victims' position, we now focus on the implications of a marginal increase in $Y$. In terms of figures 3 and 4 , a marginal increase in $Y$ is a horizontal movement from left to right. From figure 3 we may learn whether a small increase in $Y$ leads to a change in cartelists' behavior. And from figure 4 we can see whether there will be a change in consumers' expected net loss.

In most cases a small increase in $r$ will not lead to a change in the firms' behavior. The outcome will remain in the same category. In some cases a small increase in $r$ may lead to a change in behavior. In terms of figure 3, a small increase in $Y$ may imply that the border between two categories will be crossed. Based on figure 3 , table 7 gives a description of transitions that may be caused by an increase in $\Upsilon$.

\footnotetext{
47 There are, apart from these three variables, more policies that could influence the effectiveness of competition policy. One could, for instance, change the structure of leniency programs. This would affect the pay-off matrices and, consequently, the behavior of (potential) cartelists. See for instance Buccirossi, Marvão \& Spagnolo supra note 25 or Catarina Marvão \& Giancarlo Spagnolo, On Leniency, Damages and Deterrence, FREE POLICY BRIEF SERIES (2015,) https://freepolicybriefs.org/wpcontent/uploads/2015/02/freepolicybriefs_feb9.pdf.
} 
Table 7. Implications of an improvement in the position of victims

Transition Interpretation

Explanation

Implication

a. Cat. $2 \rightarrow$ Cat. 1 No cartel in period 1 rather than applying for leniency in period 1 .

b. Cat. $2 \rightarrow$ Cat. 3 No leniency in period 1 rather than leniency in period 1

c. Cat. $5 \rightarrow$ Cat. 3 No cartel in period 2 rather than cartel without leniency in period 2 .

An improvement in the position of victims implies that applying for leniency becomes more expensive for members of a cartel. Consequently, firms that would apply for leniency in period 1 may be better off by not participating in a cartel in the first place.

An improvement in the position of victims implies that applying for leniency becomes more expensive for members of a cartel. Consequently, firms that would apply for leniency in period 1 may be better off by not applying for leniency in period 1.

An improvement in the position of victims implies an increase in the risk of having to pay damages for two periods. Consequently, firms may be better off by not participating in a cartel in period 2 .

d. $\quad$ Cat. $4 \rightarrow$ Cat. $5 \quad$ Not applying for leniency in period 2 rather than applying for leniency in period 2.

e. $\quad$ Cat. $4 \rightarrow$ Cat. 2 Applying for leniency in period 1 rather than applying for leniency in period 2 .

f. $\quad$ Cat. $2 \rightarrow$ Cat. 5

Not applying for leniency in both periods rather than applying for leniency in period 1 .
An improvement in the position of victims implies that applying for leniency becomes more expensive for members of a cartel. Consequently, firms that would apply for leniency in period 2 may be better off by not applying for leniency in period 2 .

An improvement in the position of victims implies that applying for leniency in period 2 becomes more expensive for members of a cartel. Consequently, a firm may be better off by not participating in a cartel in period 2 . Therefore, the reason for not applying for leniency in period 1 may disappear.

An improvement in the position of victims implies that applying for leniency becomes more expensive for members of a cartel. Consequently, firms that would apply for leniency in period 1 may be better off by not applying for leniency in period 1.
An improvement in the position of victims may strengthen the deterrent function of the enforcement of competition law, such that firms decide not to form a cartel at all.

An improvement in the position of victims may be such that firms decide not to apply for leniency in period 1 because follow-on damages become too expensive. The firms still do not enter into a cartel in period 2. So, deterrence is not affected here.

An improvement in the position of victims may strengthen the deterrent function of the enforcement of competition law, such that firms decide not to form a cartel in period 2 .

An improvement in the position of victims may be such that firms decide not to apply for leniency anymore

without affecting their decision to form a cartel in period 2

An improvement in the position of victims may induce firms to apply for leniency in an earlier phase.

Thus conceived, an improvement in the position of victims strengthens incentives to apply for leniency. Since firms now apply for leniency in period 1 , there will be no cartel in period 2. Therefore, deterrence is increased.

An improvement in the position of victims may be such that firms decide not to apply for leniency in period 1 because follow-on damages become too expensive. The firms now enter into a cartel in period 2. Therefore, deterrence is reduced. 
We now turn to the implications of an improvement in the victims' legal position for consumer welfare. These implications can be seen in figure 4 .

As explained above, in most cases an increase in $Y$ will have no influence on the outcome in both periods. Nevertheless, the consumers' expected net loss tends to decrease. Consider, for instance, the case with a fine equal to 5 , and consider a movement within category 2. Figure $4 \mathrm{c}$ shows that the victims' expected net-loss is 10 if $Y=0$. An increase in $Y$ leads to a decrease in the expected net loss. So, victims are better off. The reason is straightforward. Cartelists apply for leniency and victims receive partial compensation. An increase in $r$ then leads to an increase in compensation. Similar remarks apply to movements within the other categories. Of course, a movement within category 1 has no consequences, since there is no cartel. A final remark concerns the situations in which the probability of detection is zero. In that case a change in the victims' legal position has no consequences at all.

In some cases, an increase in $r$ may lead to a change in firms' behavior. These changes may have implications for the consumers' expected net loss. This can be seen from figure 4.

The transitions described in table 7 have implications for leniency, deterrence and consumers' expected net loss. These implications are concisely summarized in table 8.

Table 8. Implications for leniency, deterrence and the consumers' expected net loss

\begin{tabular}{llccc}
\hline & Transition & Leniency & Deterrence & $\begin{array}{c}\text { Consumers' } \\
\text { expected net loss }\end{array}$ \\
\hline a. & Cat. $2 \rightarrow$ Cat. 1 & Less frequent in period 1 & No cartel in period 1 anymore & Lower \\
b. & Cat. $2 \rightarrow$ Cat. 3 & Less frequent in period 1 & No change & Higher \\
c. & Cat. $5 \rightarrow$ Cat. 3 & No change & No cartel in period 2 anymore & Lower \\
d. & Cat. $4 \rightarrow$ Cat. 5 & Less frequent in period 2 & No change & Lower \\
e. & Cat. $4 \rightarrow$ Cat. 2 & Earlier: in period 1 rather than 2 & No cartel in period 2 anymore & Lower \\
f. & Cat. $2 \rightarrow$ Cat. 5 & Less frequent in period 1 & Cartel in period 2 & Higher \\
\hline
\end{tabular}

Generally, an improvement in the legal position of victims will lead to an increase in consumer welfare. In a number of (exceptional) cases an improvement in the victims' legal positions may, however, reduce consumer welfare by increasing consumers' expected loss. These are cases in which cartelists, in response to an improvement of the legal position of victims, decide not to apply for leniency in period 1 . They enter into a cartel and do not apply for leniency. As a consequence, consumers may be worse off. In these cases an improvement in the legal position of victims drives out the incentive to apply for leniency, whereas leniency applications would provide the basis for follow-on damages claims.

\section{CONCLUSION}

Directive 2014/104/EU aims at removing practical obstacles to compensation for victims of infringements of EU competition law. The literature suggests that facilitating private damages actions tends to limit the effectiveness of leniency programs. If customers can claim compensation, the incentive to apply for leniency may vanish: paying a lower fine will be replaced by possibly even higher damages compensation.

In this paper we focused on the implications of improvements of the victims' position for the question of whether firms decide to enter into a cartel and for whether they apply for leniency. We also discussed the implications for consumer welfare. For this purpose, we developed a dynamic model. To investigate the impact of an improvement in the victims' position, we conducted several simulations. Our main findings are:

1. In most cases, a marginal improvement in the victims' legal position will not lead to a change in the behavior of (potential) cartelists.

2. Generally, a marginal improvement in the victims' legal position will lead to an increase in consumer welfare. This will not be the case if the cartel was already effectively deterred in the first period. 
3. In some cases, a marginal improvement in the victims' legal position may lead to an increase in the deterrent effect: cartelists may be better off by not starting or continuing a cartel. This clearly makes consumers better off.

4. In (exceptional) cases, a marginal improvement in the victims' legal position may lead to a change in the cartelist's behavior that makes consumers worse off. These are cases in which cartelists, in response to an improvement of the legal position of victims, decide not to apply for leniency in period 1. Rather, they enter into a cartel and do not apply for leniency.

Using a relatively simple two-period model, it appears to be possible to gain insight into the interference between leniency programs and damages actions. Both leniency and damages may influence the behavior of (potential) members of a cartel. This applies to both the decision to start or continue a cartel and to the decision to apply for leniency. A marginal improvement of the positions of victims may lead to substantial changes. In response to such a change, firms may no longer apply for leniency or they may even decide to no longer participate in a cartel. The model also shows under what conditions an improvement of the victims' position will make consumers better off. Our paper thus demonstrates the relevance of including the decision whether or not to enter in a cartel into economic models of competition law enforcement, as well as of studying the firms' decisions in a dynamic context.

Our findings have implications for the debate on the interplay between public and private enforcement of competition law. Clearly, private damages may drive out leniency applications. But that does not necessarily imply a decrease in the effectiveness of competition law. The reason is that facilitating private damages actions may increase the deterrent effect of competition law by discouraging firms from entering into a cartel. 